\title{
LATE RENAISSANCE GARDEN ART IN THE CARPATHIAN BASIN
}

\author{
ALBERT FEKETE \\ Szent István University, Department for Garden Art, Faculty of Landscape Architecture \\ and Urbanism Budapest, Hungary \\ *Email: fekete.albert@tajk.szie.hu
}

Received 2 June 2020, accepted in revised form 12 July 2020

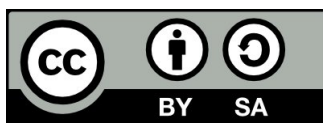

\begin{abstract}
The aim of the article was to find, scientifically define and locate the most frequent occurrences of the Late Renaissance garden units of the Carpathian Basin. This article - as partial result of a research work entitled "Castle Garden Inventory in the Carpathian Basin" and conducted by teachers and students of the Faculty of Landscape Architecture and Urbanism of Szent István University, Budapest - aims to identify through historical research, on-site visits and assessments the current status of 148 Late Renaissance residency gardens located in seven different countries of the Carpathian Basin (Austria, Hungary, Slovakia, Ukraine, Romania, Croatia and Slovenia). Based on the archival and literary sources as well as the field studies carried out, we defined the spatial distribution of Late Renaissance residential gardens, we delineated six very characteristic Late Renaissance garden units and we defined the most typical Late Renaissance garden features for the region. At the same time, we explored and documented still existing values of garden history at some locations from the Renaissance era.
\end{abstract}

Keywords: garden history, landscape renewal, Renaissance garden, environmental art, Eastern Europe, historic garden, castle garden, Carpathian Basin, landscape architecture

\section{Introduction}

\section{Background}

As far as the Carpathian Basin is concerned, we have very little processed data on Late Renaissance garden history. However, the era is of great garden-historical significance as the Battle of Mohács in 1526, ending with the victory of the Turks, caused a major break not only in the history of the region, but in its culture and landscape, as well. In the course of the 16th and 17th centuries a huge part of the Carpathian Basin, namely Western Hungary, Upper Hungary and Transylvania, became the last bastions of the spiritual and material heritage and that of the continuity of Christian European culture. (Köpeczi, 1986; Kovács, 2003). In the areas torn apart, the fulfilment of humanistic ideas was overshadowed by the struggle for survival. It is no coincidence, therefore, that the cinquecento garden art created by King Matthias Corvinus - and also praised by Bonfini - was discontinued in the Carpathian Basin in the 15th century. Although the decline of the garden culture in the entire Carpathian Basin is evident in the period following the reign of Matthias, we can still encounter examples of it, according to Emich (Emich, 1886) "pompous parks 
at the Nádasdy and Rákóczi estates such as Kolozsvár, Sárospatak and Pozsony, Sopron, Moson counties" in the landscapes spared by the Ottomans.

\section{Objectives}

The main objective of the research is the thorough and systematic literature review of the Late Renaissance (17th century) garden culture of the Carpathian Basin, the synthesis and supplementation of the contemporary garden history of the area, based on archival sources. In the study the spatial location, the characteristic elements and functional units of the explored gardens are complemented by garden memories found during site visits and field work.

\section{Renaissance garden art in the Carpathian Basin and Hungary}

While in most countries outside Italy this Renaissance idea spread only at the beginning of the 16th century, the style appeared very early in the Carpathian Basin - and thus in Hungary: at around 1470. The launch of the style was underpinned by Hungary's strong political, dynastic and cultural ties with Italythe dominant factor of which having been the marriage of King Matthias to Aragonian Beatrix in 1474. What followed as a direct consequence of the matrimony was the influx of notable Italian painters, sculptors and architects of the early Renaissance to the Hungarian Royal Court. (Dercsényi, 1951; Szakáj, 1959)

The first Hungarian Early Renaissance building was the Royal Palace of Buda. Its designer, the Italian Camicia Chimenti, furnished it with special features such as the hanging garden, the main garden built between 1479 and 1484, or the New-World Garden (with mazes, walk porches, shapetrimmed trees and bushes). This first, early period of the Renaissance in the Carpathian Basin told about the royal court and its immediate surroundings, and it lasted until the death of King Matthias in 1490. (Herczeg, 2000) Beside the Buda Castle the Royal Palace,
Visegrád had a famous garden, rooted in the Middle Ages and renewed in a Renaissance style by King Matthias, but totally destroyed during the Ottoman invasion. (Szikra, 2003) The renewal of the Visegrád castle garden has been finished in several etapes during the 20-21st centuries.

The second period of the Hungarian Renaissance comprises the decades following the death of Matthias, with Mohács marking its end in 1526. In this period the Renaissance lifestyle spread and struck root in the lives of noble courts of the Carpathian Basin. The third and the longest Renaissance era is the one following 1526 and lasting till the end of the 17th century (in the eastern regions even the beginning of the 18th century), the Late Renaissance. The research primarily focuses on this period, since the Renaissance doctrines spread in the Carpathian Basin most extensively during this era, those being prevalent not only in the noble families, but also in the manor houses of small nobles as well as bourgeois families. (Kovács, 2003)

While in the first two periods the spiritual movement developed mainly thanks to the Italian and Western European relations, the Late Renaissance bears the marks of the isolation and different cultural impacts caused by the Turkish occupation - resulting in specific forms of local characteristics: in this period the garden memories are particularly rich and interesting in Transylvania, Western and Upper Hungary.

The two distinguished Hungarian garden history researchers, Raymund Rapaics and Imre Ormos hold offer opposing views when considering the impact of the Ottoman Empire, which had grown due to centuries of conquest, on the development of garden culture. (Rapaics, 1940; Ormos, 1967)

While Ormos clearly stands up for Turkish influence, Rapaics argues that “... the Turks had no direct impact on Hungarian horticulture. It is a misconception that Turkish prisoners or Turkish armies brought flowers to uninhabited parts of Hungary. Even the Transylvanian ambassadors visiting 

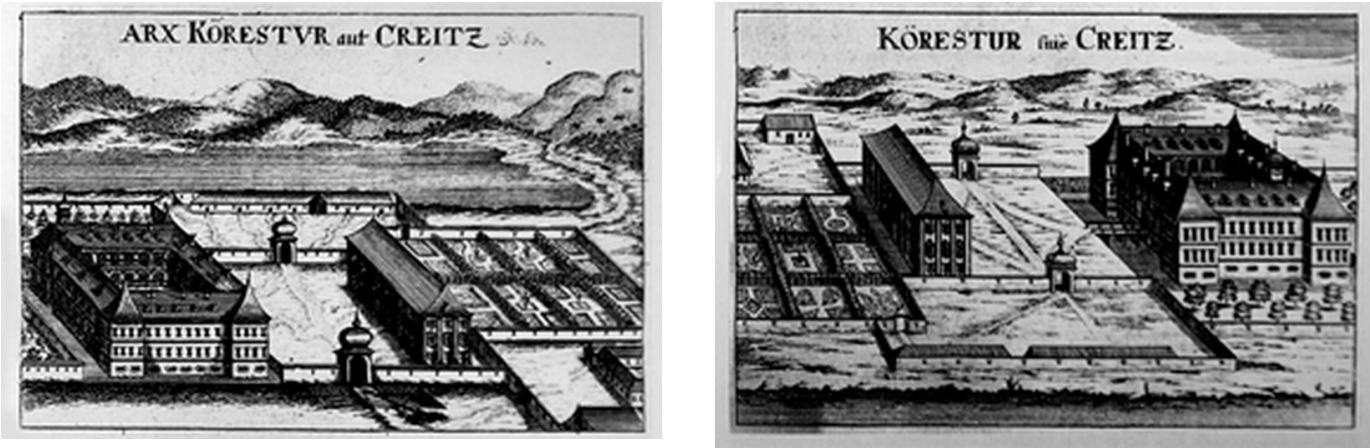

Fig. 1. Graphical representation of the Nádasdy castle from Sopronkeresztúr (Deutschkreuz, Austria) and the compartimented Renaissance gardens beside the castle building.

Gravures of M. Greischer, 1680. (Stirling, 1996)

the Turkish Sublime Porte could not lay hands on such things". (Rapaics, 1940) This statement by Rapaics is also supported by Lajos Csérer (Csérer,1929) who writes, based on Anna Bornemissza's diary of 1672, that the princess orders Tamás Gyulai to "send pomegranate and orange saplings", but Gyulai replies that he cannot comply on account that those should be brought from overseas, from Asia Minor, making them too expensive. It is certain that the 17 th-century Transylvanian gardens had their place by Turkish standards as well. It comes downs to us via the Turkish traveler Evlija Cselebi, amongst others, who in the accounts of his Transylvanian and Hungarian travels from 1660 to 1664 clearly portrays the landscape features of many settlements and the horticultural habits of those living there. In his visit to Megyesvár (Medias, R0) in 1661, as a guest of Princess Anna Bornemissza, he enjoyed a lavish reception, of which he reports: "she threw a party in a garden akin to that of Irem, a rose grove resembling paradise and by language impossible to tell or describe". (Cselebi, 1985)

During the Turkish occupation, the patronage of Hungarian culture and science was primarily associated with the Nádasdy and Batthyány families in the Western Hungarian parts, as illustrated in Figure 1.

At the same time, the Transylvanian Principality was living its golden age when Gábor Bethlen, I. György Rákóczi and I.
Mihály Apafi were the ones who financed the flourishing period of the country. The gardens of Mihály Apafi and his wife Anna Bornemisza at Ebesfalva (Dumbraveni, RO), Küküllővár (Cetatea de Balta, RO), Székely (Sacueni, R0), Radnót (Iernut, RO) and Fogaras (Fagaras, RO) were also famous for their time in the independent principality of Transylvania in the 17th century. Their gardener, Péter Háji planted fruit trees in Ebesfalva and Fogaras, and built an ornamental garden: "rosegrove, lilies, reseda, pansy, lily of the valley, larkspur blossomed under the shadowy linden trees, and in the cypress groves and all over streamlets watered the flower beds; the Radnót princely garden was also magnificent, the 1667 accounts speak of a cost of 400 forints" (Biró, 1943)

The principality taken over from Prince Gábor Báthory owed its economic upswing to Gábor Bethlen's consistent countrybuilding policy. The economic development of Transylvania, the great fortune of prince György Rákóczi I., who succeeded Bethlen, as well as the love of gardens felt by Zsuzsanna Lórántffy, Rákóczi's wife - allowed the spread of gardening in the eastern part of the Carpathian Basin. Famous from this time are the princely trellis, the two-storey summer house and the fruit preserve of the gardens at Porumbák (Porumbacu de Sus, RO), Görgényszentimre (Gurghiu, RO) and Fogaras (Fagaras, RO). Its rules are also based on the responsible thinking of a good farmer, 
such as the martial statute, which states: "Nobody should dare fell or trim a fruit tree. Anyone refuting this order shall be beaten up. Damage to the vineyards is forbidden. Do not take there a horse ... because the one who does so will first be struck thrice, the second time will cause his deprivation of everything, the third occasion will get him killed." (Köpeczi, 1986)

With regard to periods of history of style we can state that the fact that there are many places in the Carpathian Basin where Renaissance still rules at the turn of the 1718th centuries - is also attributable to the Turkish rule.

\section{Research methodology}

Description, analysis and comparison from the viewpoint of garden history requires a systematic and explicit approach. Our research approach is based on the principles of case study research. (Brink, 2016) So each site is considered as a case study and analyzed separately before a comparison is made. In the analysis we used an explicit analytical framework in order to be able to compare different sites with different geographical, economical and architectural contexts by different owners. Methods of data collection: comprising first of all a quantitative investigation of the existing archival (primary and secondary) sources and materials - descriptions, statements, land registrations, inventories, which incorporate qualitative aspects, methods - resulting in a first overview per case.

The research was conducted in four phases:

(1) Identification of all Renaissance sites (settlements, residences) in the study area, by examining and mapping of their spatial / geographic location.

(2) Determination of three fundamental types, based on the data of the researched locations:

- Type A: sites where the garden is not only mentioned but described specifi- cally with its parameters;

- Type B: sites where the garden is just mentioned, the existence of one or more gardens is present, but no description of its delineation can be found;

- Type C: sites where there is no word about a garden, apart from a building; these latter ones are not relevant to our research, so we will not deal with them further.

(3) Investigation and analyzis of type A sites, according to the elements and functional units found in the descriptions, as follows:

- the research of the distinct, clearly separable garden units, elements and functions of the era;

- the denomination and definition of the particular garden units and elements used in Late Renaissance (based on Hungarian and international literature);

- the investigation and the analysis of the locations of the individual garden units and their elements in the study area;

- the analysis of the frequency of each typical garden unit and its element;

- the search in each case for still existing ancient garden units or items, or any traces or memories of them.

(4) Documentation and interpretation in a European context (Creighton, 2009; Fekete, 2004; Fekete, 2006; Fekete, 2007; Fekete, 2008; Fekete, 2012; Fényes, 1851; Gy.Dávid, 2006; Herczeg, 2006; Hobhouse, 1992; Hunt, 1996; Hyde, 2016; Lazzaro, 1990; Marczali, 2001; Morgan, 2016; Sárospataki, 2014; Steenbergen, 1996; Strong, 1984; Szabó, 2000; Szafranska, 1989; Toman, 1995; Tüdős, 1998) of the results of archival research, analysis and fieldwork.

\section{Results and discussion}

The aristocratic gardens of the period in question were of a mixed character, merging the concepts of the vegetable and ornamental garden. If we classify the various garden types 


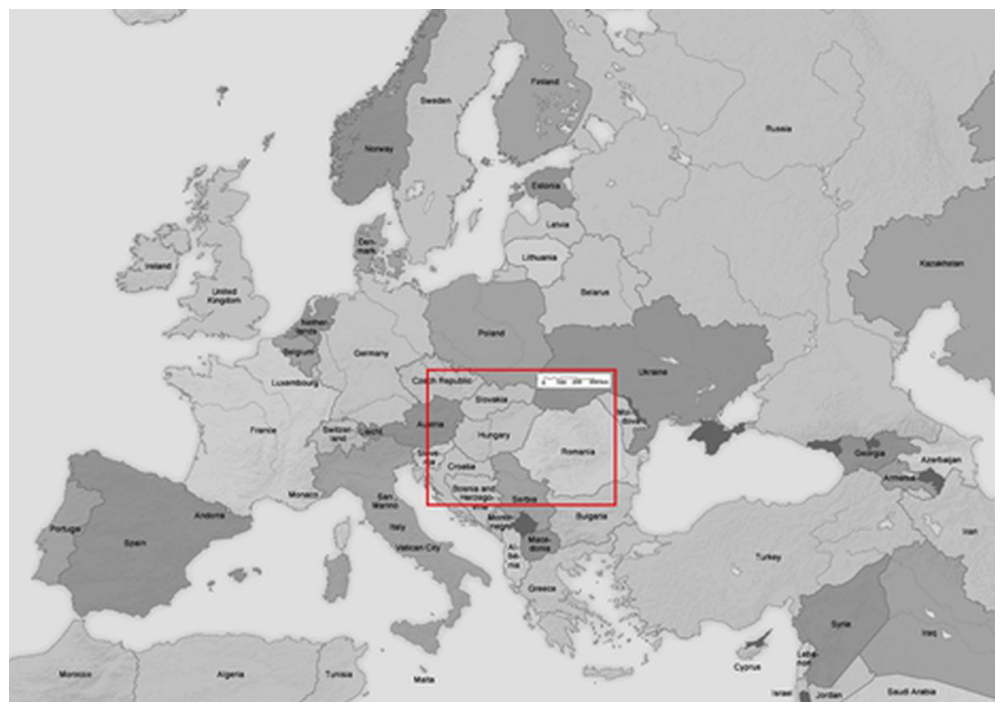

Fig. 2a. Political map of central Europe nowadays (detail) with the designated study area Source: Prepared by the author

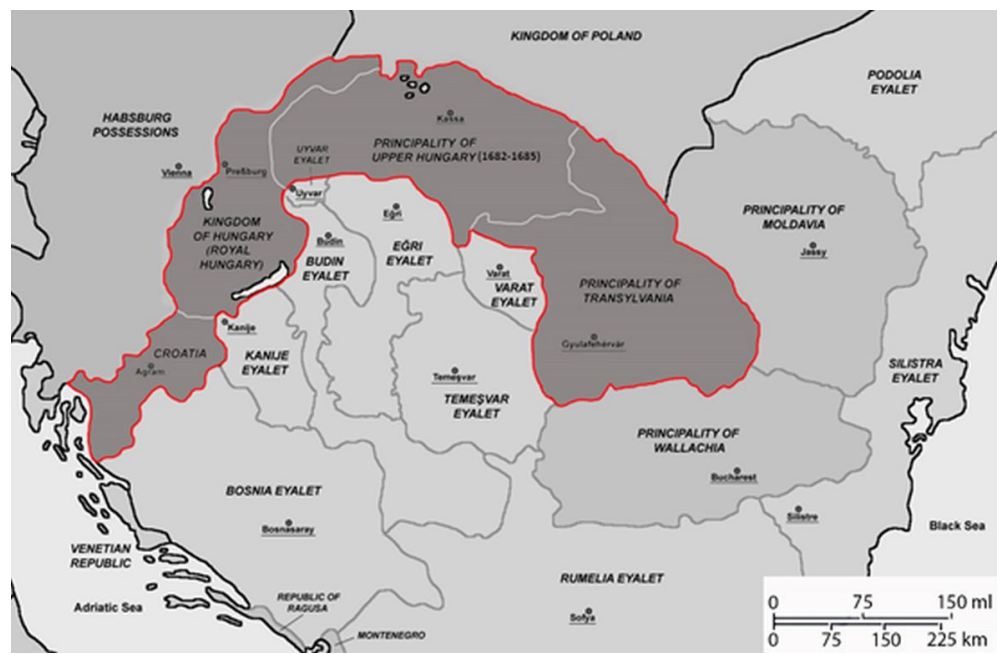

Fig, 2b. Map of Central Europe in the middle of 17th Century, showing clear the expansion of the

Ottoman Empire and the borders of non-occupied territories (Transylvanian Principality, Upper Hungary and Western Hungary)

Source: Prepared by the author using as source the Encyclopedia Britannica, 1998

according to the plant species found in them, the gardens of the late Renaissance period should be considered vegetable-flower gardens, geometrically compartmented garden with some built elements. As early as the beginning of the sixteenth century the compartiment - in which the flowers were planted in regular order and with geometrical precision - became the central part of ornamental gardens throughout Europe. Because of the "cultural lag" this garden motif, like many others, also appeared in Eastern Europe after a century's delay. The distribution of the compartiments was at once science and art, and horticultural handbooks taught in this era the design of the compartimented garden. 


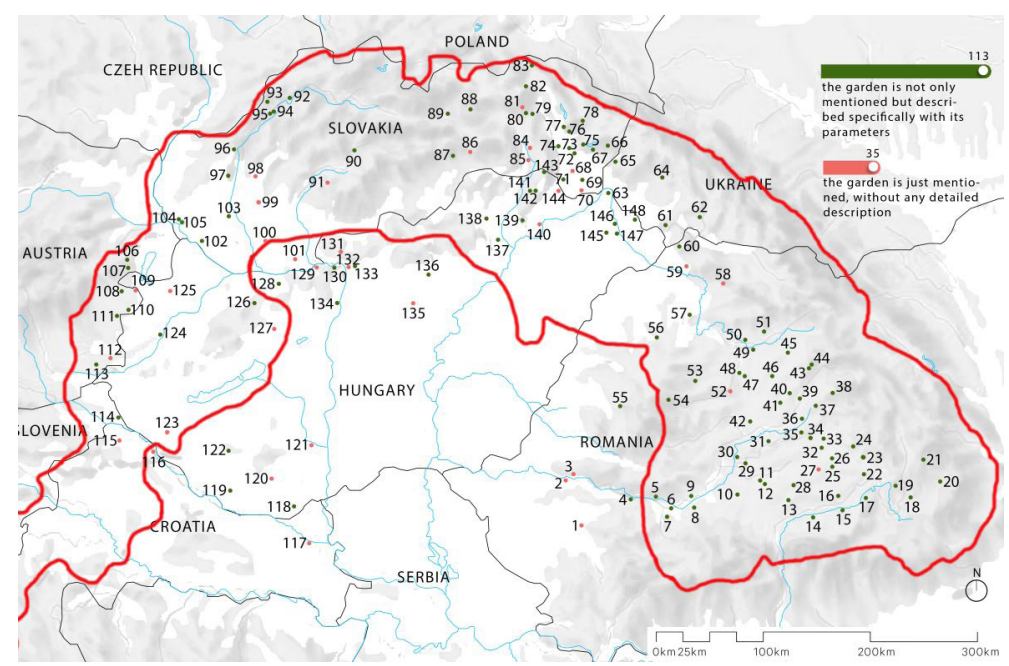

Fig. 2c. Location map of the investigated late Renaissance gardens, prepared by the Author. The comparative analysis of the spatial distribution and the political map of the Carpathian Basin in the 17th Century

\section{Identification of Late Renaissance gardens/sites - spatial distribution}

The study area is located in Central and Eastern Europe, illustrated in Figure 2a.

During the archival research 148 sites where we can state that there was a Late Renaissance garden were discovered. The mapping of the identified sites clearly shows their spatial location within the Carpathian Basin. The region being strongly influenced by the Ottoman Empire during the 16-17th centuries, it was very important to define the location of each investigated site related to the political map of the 17th Century, illustrated in Figure $2 b$, overlapped with the current country borders from the region, illustrated in Figure 2c.

The comparative analysis of the site locations and the political map of the Carpathian Basin in the 17th Century supports the hypotheses claiming that in the 16-17th Centuries Renaissance culture - and as part of it the garden culture - was missing or only existed to a very little extent, being sporadically present in the territories occupied by the Turks. In contrast, there were a large number of Late Renaissance residences, with their surrounding gardens, in the unoccupied territories of the Carpathian Basin (Transylvanian Principality, Upper Hungary and Western Hungary).

Of the 148 locations identified, in 113 cases specific descriptions document in detail the existence of the garden, its units and elements ("type A"). In 35 cases the garden is only mentioned, that is, the existence of one or more gardens is referred to, but no specific description of them is to be found ("type B"). The geographical distribution and the names of the locations are represented in Figure 2c and Table 1.

\section{Definition of Late Renaissance garden units}

We defined a garden unit as a garden or garden section with independent denomination and function. We investigated and analyzed the frequency of occurrences and location of each garden unit. In the case of "type A" sites, we located a total of six characteristic garden units on the basis of the descriptions, and which occurred regularly in the examined Late Renaissance gardens. These were defined individually by the Hungarian and international literature. 
Table 1. The list of investigated sites. The numeration marks the spatial distribution of the sites on the map from the figure 2c. Source: Prepared by the author

\begin{tabular}{|c|c|c|c|c|c|}
\hline No & $\begin{array}{l}\text { Hungarian } \\
\text { (original) } \\
\text { denomination of } \\
\text { the settlement }\end{array}$ & $\begin{array}{l}\text { Actual official } \\
\text { denomination of the } \\
\text { settlement and its } \\
\text { location } \\
\text { (country) }\end{array}$ & No & $\begin{array}{l}\text { Hungarian } \\
\text { (original) } \\
\text { denomination of } \\
\text { the settlement }\end{array}$ & $\begin{array}{c}\text { Actual official } \\
\text { denomination of the } \\
\text { settlement and its } \\
\text { location } \\
\text { (country) }\end{array}$ \\
\hline 1 & Lugos & Lugoj, RO & 34 & Kóródszenmárton & Coroisanm. RO \\
\hline 2 & Lippa & Lipova, RO & 35 & Nagyteremi & Tirimia, RO \\
\hline 3 & Odvos & Odvos, RO & 36 & Marosszentkirály & Sancr Mures, RO \\
\hline 4 & Marosillye & Ilia, RO & 37 & Gernyeszeg & Gornesti, RO \\
\hline 5 & Branyicska & Branisca, RO & 38 & Görgényszentimre & Gurghiu, RO \\
\hline 6 & Kisbarcsa & Barcea Mica, RO & 39 & Nagyercse & Ercea, RO \\
\hline 7 & Vajdahunyad & Hunedoara, RO & 40 & Mezőörményes & Urmenis, RO \\
\hline 8 & Szászsebes & Sebes, RO & 41 & Mezőzáh & Zaul de Campie, RO \\
\hline 9 & Algyógy & Geoagiu, RO & 42 & Gerend & Luncani, RO \\
\hline 10 & Drassó & Drasov, RO & 43 & Paszmos & Posmus, RO \\
\hline 11 & Szászcsanád & Cenade, RO & 44 & Nagysajó & Sieu, RO \\
\hline 12 & Sorostély & Sorostin, RO & 45 & Kentelke & Chintelnic, RO \\
\hline 13 & Borberek & Vurpar, RO & 46 & Búza & Búza, RO \\
\hline 14 & Alsóárpás & Arpasu de Jos, RO & 47 & Gyeke & Geaca, RO \\
\hline 15 & Fogaras & Fagaras, RO & 48 & Kendilóna & Luna de Jos, RO \\
\hline 16 & Sáros & Soars, RO & 49 & Szentbenedek & Manastireni, RO \\
\hline 17 & Komána & Com de Sus, RO & 50 & Kaplyon & Coplean, RO \\
\hline 18 & Sepsiköröspatak & Valea Crisului, RO & 51 & Négerfalva & Negrilesti, RO \\
\hline 19 & Miklósvár & Miclosoara, RO & 52 & Szamosfalva & Somesen-Cluj, RO \\
\hline 20 & Kézdiszentlélek & Sanzieni, RO & 53 & Egeres & Aghires, RO \\
\hline 21 & Csíkkozmás & Cozmeni, RO & 54 & Zentelke & Sancraiu, RO \\
\hline 22 & Pálos & Palos, RO & 55 & Belényes & Beius, RO \\
\hline 23 & Bögöz & Mugeni, RO & 56 & Szilágysomlyó & Simleul Silv. RO \\
\hline 24 & Siménfalva & Simonesti, RO & 57 & Szilágycseh & Cehu Silv. RO \\
\hline 25 & Sárpatak & Sarpotoc, RO & 58 & Nagybánya & Baia Mare, RO \\
\hline 26 & Nagybún & Boiu, RO & 59 & Aranyosmeggyes & Med Auriu, RO \\
\hline 27 & Keresd & Cris, RO & 60 & Halmi & Halmeu, RO \\
\hline 28 & Martonfalva & Metis, RO & 61 & Tiszaújhely & Nove Selo, UKR \\
\hline 29 & Búzásbocsárd & Buc Granoasa, RO & 62 & Huszt & Hust, UKR \\
\hline 30 & Meggykerék & Mescreac, RO & 63 & Tiszaszentmárton & $\mathrm{HU}$ \\
\hline 31 & Magyarbükkös & Bichis, RO & 64 & Szentmiklós & Cinadno, UKR \\
\hline 32 & Szásznádas & Nades, RO & 65 & Ungvár & Uzsgorod, UKR \\
\hline 33 & Szentdemeter & Dumitreni, RO & 66 & Sajótiba & Tiba, SK \\
\hline
\end{tabular}




\begin{tabular}{|c|c|c|c|c|c|}
\hline No & $\begin{array}{l}\text { Hungarian } \\
\text { (original) } \\
\text { denomination of } \\
\text { the settlement }\end{array}$ & $\begin{array}{l}\text { Actual official } \\
\text { denomination of the } \\
\text { settlement and its } \\
\text { location } \\
\text { (country) }\end{array}$ & No & $\begin{array}{l}\text { Hungarian } \\
\text { (original) } \\
\text { denomination of } \\
\text { the settlement }\end{array}$ & $\begin{array}{c}\text { Actual official } \\
\text { denomination of the } \\
\text { settlement and its } \\
\text { location } \\
\text { (country) }\end{array}$ \\
\hline 67 & Magyar-Jesztreb & Zem Jastrabie, SK & 100 & Érsekújvár & Nove Zamky, SK \\
\hline 68 & Garany & Hran, SK & 101 & Köbölkút & Gbelce, SK \\
\hline 69 & Zétény & Zatín, SK & 102 & Nagyszarva & Rohovce, SK \\
\hline 70 & Nagygéres & Velky Hores, SK & 103 & Galánta & Galanta, SK \\
\hline 71 & Borsi & Borsa, SK & \multirow{2}{*}{104} & \multirow{2}{*}{$\begin{array}{l}\text { Pozsony- } \\
\text { nádorkert }\end{array}$} & \multirow{2}{*}{ Bratislava, SK } \\
\hline 72 & Bánóc & Bánovce, SK & & & \\
\hline 73 & Tussa & Tusice, SK & 105 & Pozsony-érsekkert & Bratislava, SK \\
\hline 74 & Bacskó & Backov, SK & 106 & Kismarton & Eisenstadt, AU \\
\hline 75 & Nagymihály & Michalovce, SK & 107 & Cinfalva & Siegendorf, AU \\
\hline 76 & Hrabóc & Hrabovec, SK & 108 & Sopronkeresztúr & Deutschkreuz, AU \\
\hline 77 & Varannó & VranovToplou, SK & 109 & Lakompak & Lackenbach, AU \\
\hline 78 & Homonna & Humenné, SK & 110 & Borsmonostor & $\begin{array}{c}\text { Klostermarienberg, } \\
\mathrm{AU}\end{array}$ \\
\hline 79 & Terjékfalva & Teriakovce, SK & 111 & Léka & Lockenhaus, AU \\
\hline 80 & Eperjes & Presov, SK & 112 & Németújvár & Güssing, AU \\
\hline 81 & Nagysáros & Velky Saris, SK & 113 & Királyfalva & Königsdorf, AU \\
\hline 82 & Hertnek & Hertnik, SK & 114 & Hosszúfalu & Dolga vas, SLO \\
\hline 83 & Zboró & Zborov, SK & 115 & Csáktornya & Cakovec, CRO \\
\hline 84 & Kassa & Kosice, SK & 116 & Légrád & Legrad, CRO \\
\hline 85 & Enyicke & Haniska, SK & 117 & Eszék & Osijek, CRO \\
\hline 80 & Jánova vára & Stitnil $\mathrm{CK}$ & 118 & Magyarbóly & Magyarbóly, HU \\
\hline 81 & Csetnek & Stitnik, SK & 119 & Várad & Várad, HU \\
\hline 88 & Lócse & Levoca, SK & 120 & Pécs & Pécs, HU \\
\hline 89 & Folsø̋micciny & Spissky Stiavnik, SK & 121 & Szekszárd & Szekszárd, HU \\
\hline 90 & Felsőmicsinye & Horná Micina, SK & 122 & Szenna & Szenna, HU \\
\hline 91 & Selmecbánya & $\begin{array}{l}\text { Banska Stiavnica, } \\
\text { SK }\end{array}$ & 123 & Kanizsa & Kanizsa, HU \\
\hline 92 & Vágbeszterce & Považská Bystrica, & 124 & Sárvár & Sárvár, HU \\
\hline 92 & vagbeszterce & $\mathrm{SK}$ & 125 & Kapuvár & Kapuvár, HU \\
\hline 93 & Vöröskő & Červený Kameň, SK & 126 & Kisbér & Kisbér, HU \\
\hline 94 & Kasza & Koseca, SK & 127 & Csurgó & Csurgó, HU \\
\hline 95 & Ilava & Ilava, SK & 128 & Tata & Tata, HU \\
\hline 96 & Csejte & Cachtice, SK & 129 & Esztergom & Esztergom, HU \\
\hline 97 & Nagykosztolány & Vel'ké Kostol'any, SK & 130 & Visegrád & Visegrád, HU \\
\hline 98 & Pacola & Obsolovce, SK & 131 & Nógrád & Nógrád, HU \\
\hline 99 & Nyitra & Nitra, SK & 132 & Vác & Vác, HU \\
\hline
\end{tabular}




\begin{tabular}{ccc}
\hline No & $\begin{array}{c}\text { Hungarian } \\
\text { (original) } \\
\text { denomination of } \\
\text { the settlement }\end{array}$ & $\begin{array}{c}\text { Actual official } \\
\text { denomination of the } \\
\text { settlement and its } \\
\text { location } \\
\text { (country) }\end{array}$ \\
\hline 133 & Rád & Rád, HU \\
134 & Buda & Buda, HU \\
135 & Jászberény & Jászberény, HU \\
136 & Ludas & Ludas, HU \\
137 & Ónod & Ónod, HU \\
138 & Sajókeresztúr & Sajókeresztúr, HU \\
139 & Szerencs & Szerencs, HU \\
140 & Tokaj & Tokaj, HU \\
\hline
\end{tabular}

\section{Flower garden}

Most of them are formal gardens planted with herbaceous flowers, often decorated with herbs and spices, in regular order. Of the explored sites, 60 places are mentioned as flower gardens. Despite the fact that the flower garden was primarily decorative, it appears in many places (in 23 cases) together with vegetable gardens/allotments.

"The design of the flower garden depends closely on the arrangement of the landscape as well, and is the reflection of a lifestyle, a perspective, a philosophy and a differing socio-economic development. With their flowers, the late Renaissance gardens of the Carpathian Basin were also the gardens of reality and freedom, because of the pomp of the West and the Turkish dependency of the East. The symbol of national freedom at this time is the garden, where in addition to the flowers the splendor and comfort of the pavilions showed this real world and the arising thoughts of future independence as reconcilable," write Csoma and Tüdős (Csoma, 2010) pointing out that the garden must be approached as a microcosm of the landscape, and gardening must be regarded as the forerunner of landscape formation.

A very good example in this sense is the description and graphical interpretation from 1664 of the compartimented Bishop

\begin{tabular}{ccc}
\hline No & $\begin{array}{c}\text { Hungarian } \\
\text { (original) } \\
\text { denomination of } \\
\text { the settlement }\end{array}$ & $\begin{array}{c}\text { Actual official } \\
\text { denomination of the } \\
\text { settlement and its } \\
\text { location } \\
\text { (country) }\end{array}$ \\
\hline 141 & Fóny & Fóny, HU \\
142 & Regéc & Regéc, HU \\
143 & Füzér & Füzér, HU \\
144 & Újhely & Újhely, HU \\
145 & Máda & Máda, HU \\
146 & Vásárosnamény & Vásárosnamény, HU \\
147 & Nagydobos & Nagydobos, HU \\
148 & Beregsurány & Beregsurány, HU \\
\hline
\end{tabular}

garden in Pozsony (Bratislava, SK), by György Lippay, illustrated in Figure 3:"PART V. On the Compartiments of the Flower Garden and the Arrangement of the Ornate Shapes in Them ...In order to more easily achieve the garden forms in the compartments: before you would carry it out on the ground, lay it out on paper, and execute it on the ground according to the decoration designed on the paper..." (Stirling, 2016)

The description of the flower garden belonging to the manor house in Siménfalva (Simonesti, R0, 1636), represents another interesting example from this time, the 'vegetable garden' and the 'trellis garden' being also incorporated in the flower garden. (Fekete, 2008)

The writers of the inventories could analyze the flower gardens thanks to various sources. In numerous cases whole plant lists were made of the species found there, but it also happened that the species composition was not determined on the basis of live plants but from the prepared vegetable distillates.

There are descriptions of hedges or grapevine margins in Gyeke (Geaca, RO, 1696), Kórodszentmárton (Coroisanmartin, RO, 1696), Szentbenedek (Manastirea, RO, 1696) Mezőörményes (Urmenis, RO, 1721), Vajdahunyad (Hunedoara, R0, 1681), Sorostély (Sorostin, R0, 1683), Szászcsanád 


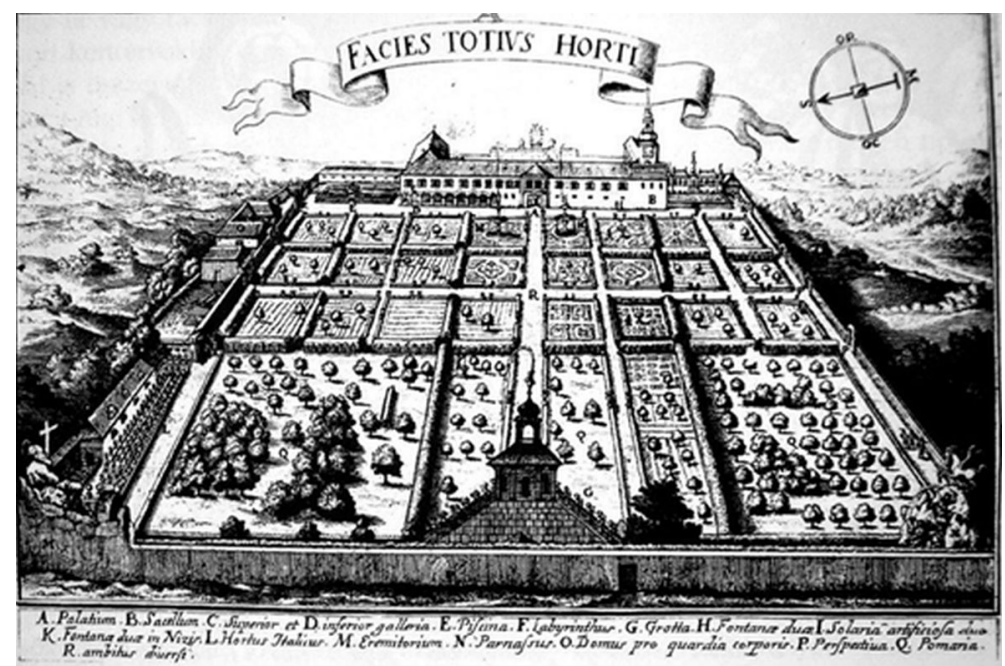

Fig. 3. Bird's-eye representation from North of the Bishop Garden from Pozsony (Bratislava, SK) in 1663. Gravure by Mauritius Lang based on a sketch of Johann Jacob Khün. (MTA)

(Cenade, R0, 1736), Nagyteremi (Tirimia, RO, 1647), Borberek (Vurpar, RO, 1694), Galac (Galatii Bistritei, RO, 1676) and Ludas (Ludus, RO, 1755). (B.Nagy, 1970)

\section{Vegetable garden}

In general, a section of a geometrical garden, mainly in ordered plantation of vegetables; if one of the planted vegetables was in a larger proportion in the garden, the garden was named after the respective vegetable variety: cabbage garden in Görgényszentimre (Gurghiu, R0, 1652), maize garden in Branyicska (Branisca, RO, 1757). Our research identified vegetable gardens on 44 sites based on the descriptions.

According to a second description of the manor house in Görgényszentimre from 1692 (Fekete, 2007), "there were two patches of carnations encircled by sage, as well as four patches of boxwood, two of which were also bordered with sage. The path dividing the patches was lined with cypresses, but the sections falling towards the Görgény creek were framed with a row of gooseberries and a row of grapes. Old garden beans and peas were cultivated at its side, at the end of the boxwood patch falling towards the South

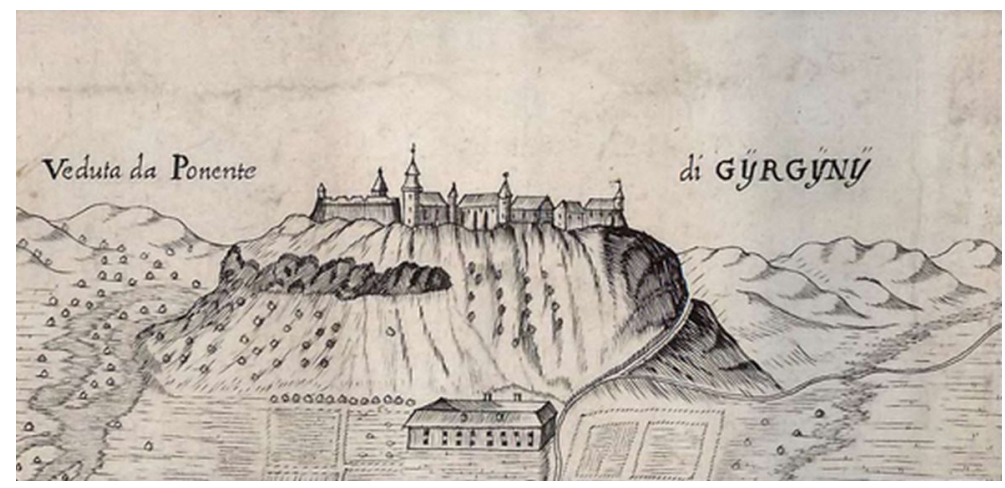

Fig. 4. Gravure of the Rákóczi Estate from Görgényszentimre (Gurghiu, R0) from 1699. The garden of the manor house located in the bottom of castle hill was described in 1692. (Archival source: Mappa della Transilvania e Provintie contique nella quales) 


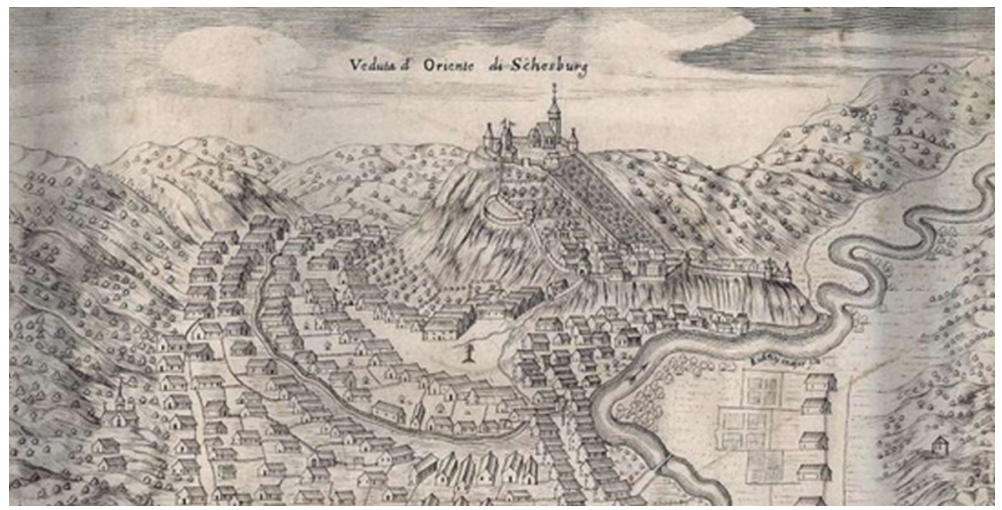

Fig. 5. Gravure of the Castle of Segesvár (Sighisoara, R0) from 1699, with orchard representations on the terraces of the western hillside. (Archival source: Mappa della Transilvania e Provintie contique nella quales)

there was a patch of lettuce surrounded with peonies. Beyond the third boxwood patch, a patch of onions and a bed of scallions were planted, bordered with seed radishes. Along the South hedge leading to the sundial, a strip of onions and a strip of tarragons were sown. One of the boxwood patches by the arbour was bordered with hyssops, directly beside which grew rows of autumn garlic, scallions and seed onion."

A simple sketch of the estate from Görgényszentimre is presented in Figure 4.

\section{Orchard}

A garden area where mostly fruit trees were planted. Similarly to the vegetable garden, the name of the garden area could also be the name after the dominant fruit variety here: sour cherry garden in Uzdiszentpéter (Sânpetru de Câmpie, RO, 1679), apple garden in Csíkkozmás (Cozmeni, RO, 1688), plum tree garden in Görgényszentimre (Gurghiu, R0, 1652). Orchards are mentioned in 39 locations in the descriptions. Orchards (or fruit trees) were very often found in flower garden - allotments, too. This category includes the following sites: Négerfalva (Negrilesti, RO, 1697), Borberek (Vurpar, RO 1701), Szásznádas (Nadasul Sasesc, RO 1712), Szászcsanád (Cenade, RO 1736) Marosszentkirály (Sancraiu de Mures, RO, 1753). (B. Nagy, 1970.) Sárpatak (Sapartoc, RO, 1736), Nagyercse (Ercea,
RO, 1750), Vajdahunyad (Hunedoara, RO, 1681), Branyicsaka (Branisca, R0, 1726), Szentbenedek (Manastirea, RO, 1784) and Mezőörményes (Urmenis, RO, 1721). (B. Nagy, 1970) Figure 5 shows a terraced orchard garden on the castle hill from Segesvár (Sighisoara, R0), at the end of 17 th century.

\section{Trellis garden}

The trellis garden was a garden section where vines were usually run on a support system, but we could find several places where fruit trees served as trellis. (Stirling 1996). Out of the researched sites we have found 37 descriptions of trellis gardens, among others in Visegrád (HU), Nagyteremi (Tirimia, MS, 1647), Drassó (Drasov, RO, 1647), Búzásbocsárd (Bucerdea Granoasa, RO, 1656), Mezőörményes (Urmenisul de Campie, R0, 1721), Branyicska (Branisca, RO, 1744), Marosszentkirály (Sancraiu de Mures, RO, 1753).

In the latter case the vine was run upon a custom-made wooden frame, unlike the other gardens, where live trees played the role of the frame. It often happened that the trellis garden, too, was developed along with the vegetable garden. Combined gardens of trellis and vegetable were featured in 12 descriptions. We have found examples of connections between the trellis garden and a summer house. Accordingly, in Magyarbükkös 
(Bichis, RO) there was a summer house in the trellis garden, while in Bethlenszentmiklós (Sanmiclaus, RO) in 1624 three arbours were constructed, each ending with summer house. (Archival source, 1646)

\section{Apiary}

Honey and beeswax played a significant role in household life in the 17 th century: "Honey was a very coveted merchandise in our monasteries and on the tables of our lords. With honey fruit conserves were made, floral waters and herbs were also mixed with. The most popular were the rosemary, rose and tarragon honies. The beloved mead also appears in most inventories of old times, and women preferred mainly honeyed wine... Almost all manors had a beekeeper, or a serf handy with bees or one who was a honeymaker. Rákóczi's wife had 1123 beehives, 133 buckets of mead, 346 buckets of honeycomb and 447 of pure honey - alone in Transylvania in 1642." (Thoroczkai, 1923)

a

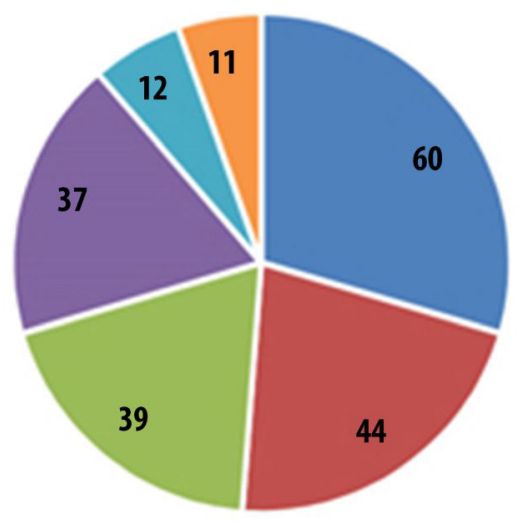

FLOWER GARDEN

ORCHARD

APIARY
In the Late Renaissance the apiary is usually a mixed garden. Here, the beehives and their scaffoldings were the elements that enabled the flower garden to function as an apiary ('bee-garden'). We found 12 apiaries mentioned in the descriptions.

An example of an apiary in a flower garden is Kendilóna (Luna de Jos, RO, 1716). We have found mentions about an orchard affiliated with an apiary in Kővár (Kamengrad, SK, 1694) and Szászcsanád (Cenade, RO, 1736). (Stirling, 1996) In addition to the aforementioned designs, cases of an apiary partnered with an allotment could be found in Galac (Galati, RO, 1676), Kentelke (Chintelnic, RO, 1690), Egeres (Aghires, RO, 1699), Mezőörményes (Urmenisul de Campie, RO, 1728) and Görgényszentimre (Gurghiu, RO, 1697), where, besides the allotment, lavender and lily are mentioned in the description. (B. Nagy, 1970) We also found an orchard and a vegetable garden shared the place with an apiary: Búza (Buza, RO, 1698). (B. Nagy, 1970; Archival source, 1692)

b

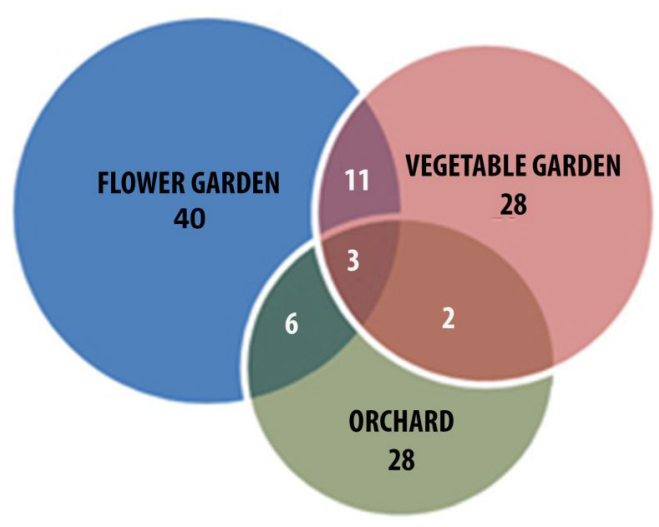

Fig. 6. Proportional distribution of different garden units discovered in the Late Renaissance gardens of the Carpathian Basin (a) and a graphical representation of the mixed character of some identified late Renaissance garden units. A considerable overlapping in between "flower gardens", "vegetable gardens" and "orchards" has been proved by descriptions (b). Source: Prepared by the author. 
As illustrated by the cases of the first five garden units, so-called mixed gardens were common: in which the trellis, the vegetable garden, the flower garden and the orchard occur together; or, the flower garden planted with nectar-rich plants forms part of the apiary garden. The relationship is illustrated in Figure 6. According to a 1653 inventory in Gerend (Grindeni, RO) there was a so-called "arboured-vegetable-fruit" Renaissance garden, whose longitudinal axis was marked by a vine arbour, to which an arbour made of 3 sour cherry and plum trees was attached perpendicularly. The geometric layout system, with a summer house in its centre, evidently marks some ornamental garden elements. The summer housevine arbour composition was a frequent one in Transylvanian Renaissance gardens. An inventory prepared eight years later mentions a mixed garden with a new summer house and fish ponds:"There is before the fish-holding ponds a good shingled summer house, whose two levels on top of each other are circular, planked and bordered all around with planed planks... and planted all around with lovely rose-trees." (Stirling, 1996)

Examples include the following gardens apart from Gerend: Kórodszentmárton (Coroisanmartin, RO), Nagykosztolány (Vel'kéKostol’any, SK), Barlabás (Barlibas, RO), Nagymihály (Michalovce, SK), Uzdiszentpéter (Sanpetru de Campie, RO), Varannó (Vranovnad Toplou, SK) and FejérházMunkács (Munkacevo, UKR). (Stirling, 1996; Archival source, 1679)

\section{Game reserve}

The game reserves were introduced as a result of the Renaissance, mainly around holds and castles. (Csőre, 1997) The research has located 11 reserves. Deer and bison were recorded in Szentdemeneter (Dumitreni, MS, 1629) and in Mezőörményes (Urmenisul de Campie, R0, 1728). In Szentdemeter there were 21 registered deer in 1629. Perhaps due to the game reserves, the favorite peacock of the Renaissance could already be found in some manor houses. There were ten of them in Szentdemeter in 1629. Besides Szentdemeter, peacocks were also noted down in Galac (Sztrigygalac - Galati, R0, 1676), Bethlen (Beclean, R0, 1690), Hosszúfalu (Satulung, RO, 1723), Zentelke (Sancraiu-Zam, R0, 1715) and in Mezőbod (Papiullarian, 1629). Black geese (Branta bernicia) and sea hare (Aplysia depilans) were registered in Uzdiszentpéter (Sanpetru de Campie, RO, 1679). (Fekete, 2008) Game reserves are also mentioned in Soborsin (Savarsin, R0) and in Gyalu (Gilau, RO, 1676), the latter stretching to the shore of Kis-Szamos, and according to the 1676 chronicle "a good well and some apple, plum and pear trees are in this game garden ... stags amounted to 6 , roebucks to 18." (Takács, 1917) The Bánffy family had another reserve not far from the one at Gyalu (Gilau, R0), known as Havasrekettyés (Rachitele, RO), the size of which is disputed. According to some sources it covered 14 , while others claimed it to have been 70 hectares. Besides deer, elk was also to be found in this game park. (Csőre, 1997)

\section{Identification of typical Late Renaissance garden features}

In the units of the Late Renaissance Hungarian gardens we have defined functional and ornamental garden elements idiosyncratic to the era, which were in an organic relationship with the gardens: garden pavilion, summer house, wooden bridge, fish pond, trellis, fence/wattle, fruit-wall, topiary, sun dial.

The research shows some Renaissance garden elements, the spread of which in the 18 th century Carpathian Basin could be traced in Baroque gardens: the grotto, and the graved and decorated stone fountain.

This article does not cover the definition and detailed discussion of the listed garden elements, those are part of a subsequent study. 
Table 2. The list of functional units with Late Renaissance roots discovered on the site during the field surveys, and its location. Source: Prepared by the author.

\begin{tabular}{cccc}
\hline Moat & Fish pond & Retaining wall & Terrace \\
\hline Borsi (Borsa, SK) & Bonyha (Bahnea, RO) & Miklósvár & Enyedszentkirály \\
Fogaras (Fagaras, RO) & Drassó (Drasov, RO) & (Miclosoara, RO) & (Sancrai, RO) \\
Gernyeszeg & Gerend(Luncani, RO) & & Gerend (Luncani, RO) \\
(Gornesti, RO) & Görgényszentimre & & Gyalu (Gilau, RO) \\
Marosvécs & (Gurghiu, RO) & Miklósvár \\
(Brancovenesti, RO) & Keresd (Cris, RO) & (Miclosoara, RO) \\
Radnót (Iernut, RO) & Miklósvár & Segesvár \\
Szászsebes (Sebes, & (Miclosoara, RO) & (Sighisoara, RO) \\
RO) Vajdahunyad & Vajdaszentivány & Visegrád, HU \\
(Hunedoara, RO) & (Voivodeni, RO) & \\
\hline
\end{tabular}

Late Renaissance garden memories in the Carpathian Basin in the present days

As described in the article, the term "Late Renaissance" mainly designates the 17 th century in the examined area. We do not have any Renaissance or Late Renaissance garden memories in the Carpathian Basin that have survived in relatively good condition. Also insignificant is the number of garden memories (garden units or items) that have been preserved in a transformed - or sporadically surviving in a modified - state, or have been seriously damaged and are often barely recognizable to be identified. The main reason for this is the long stretch of time elapsed since the heyday of the Late Renaissance in the 17 th century, which has led to the complete obliteration of garden units and elements (of rather evanescent nature when compared to buildings). Furthermore, trends in history of style having come in vogue, and differing from the

Renaissance ideals and its formal solutions, have also contributed to this destruction. The annihilation of invaluable cultural treasures, mentioned and traced back in archival sources is not the least due to the geopolitical features of the region. Local or global armed conflicts of the 1720th centuries (Ottoman invasion, II. Ferenc Rákóczi's war of independence, 1848-49 War of Independence, the Great War and World War II, as well as the nationalizations and ownership changes dictated by the subsequent communist regimes etc.) have all contributed to the fact that we can not speak of a still on site existing significant

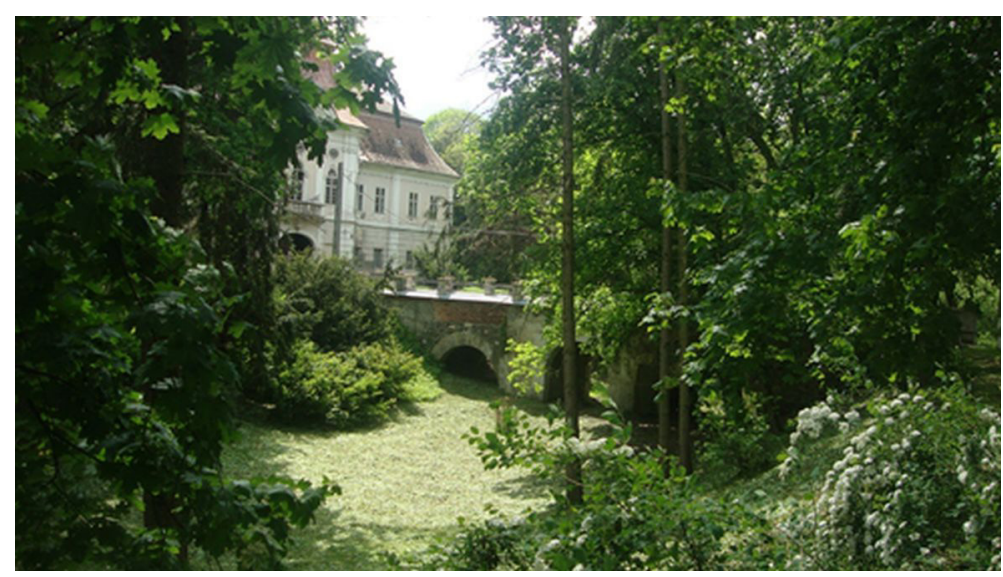

Fig. 7a. The current state of the Renaissance moat in the front of the Teleki castle from Gernyeszeg (Gornesti, Romania). Source: photo by the author, 2018. 


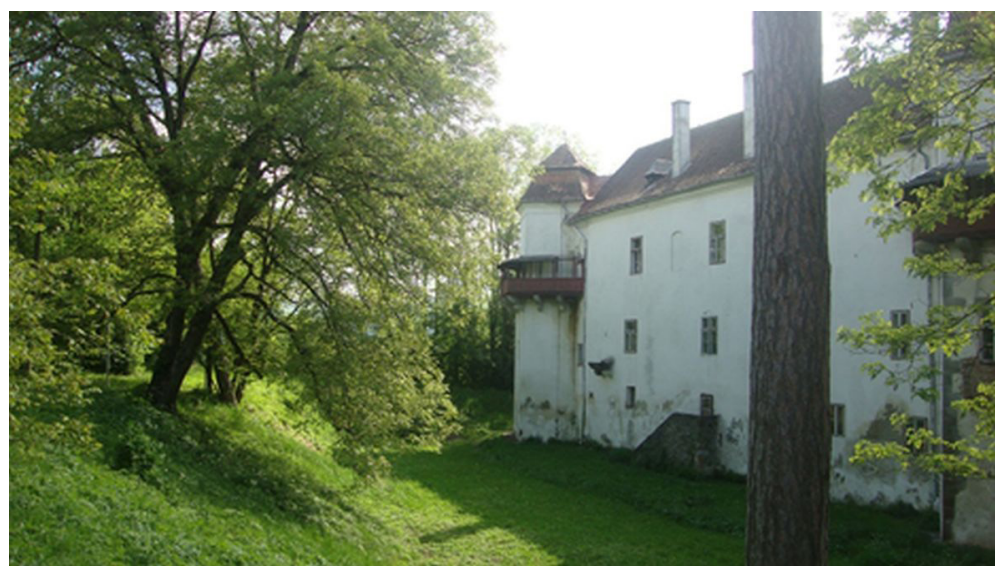

Fig. 7b. The present condition of the Renaissance moat behind the Kemény castle from Marosvécs (Brancovenesti, Romania). Source: Photo by author, 2017.

Late Renaissance garden heritage in the Carpathian Basin today.

Despite of this, in some of our investigations we have been able to identify the remains of some garden units or garden elements, like moats, fishponds, retaining walls or terraces. These are functional units or elements having resulted from large-scale fieldworks that have not totally disappeared throughout the centuries and could be identified on the site, according to Table 2 and Figure $7 \mathrm{a}$ and $7 \mathrm{~b}$.

\section{Conclusions}

- The research has collected and ordered the most important Late Renaissance gardens of the Carpathian Basin - as the main chapter of the East-European landscape history.

- Shedding light on the rapport and interaction between the contemporary European historical trends, the research offers an overview of the four-hundred-year history of the Late Renaissance gardens of the Carpathian Basin, spanning between the $17^{\text {th }}-21^{\text {st }}$ centuries.

- It proves at a significant scale the continuity of garden art arching four hundred years from the Late Renaissance till the present. With this continuum the unique position of the Late Renaissance gardens of the Carpathian Basin has been proven in comparison with other Eastern-European countries, where the link between the Renaissance and the Baroque was broken as the 17th century, Late Renaissance garden memories are rendered missing - due to the (occasionally even 150-year-long) Turkish occupation.

- The work also proves that the Late Renaissance gardens form an essential part of the Inter-Carpathian cultural heritage. Without knowing the gardenand art historical values and development of the researched gardens, the whole European garden history too would be deprived and, in some cases, obscured.

- This research forms part of the academic curriculum of landscape architecture, architecture and art history. At the same time it also plays a promoting role in the preservation of cultural historical values and landscape traditions.

- The present work raises awareness about the importance of surveys and registries and it classifies the relatively preserved garden units and elements (with the neighbouring and related landscape sections where applicable) in the group of cultural landscapes in the spirit of the European Landscape Convention.

- The study highlights the relationship and the inter-connection of the Renais- 


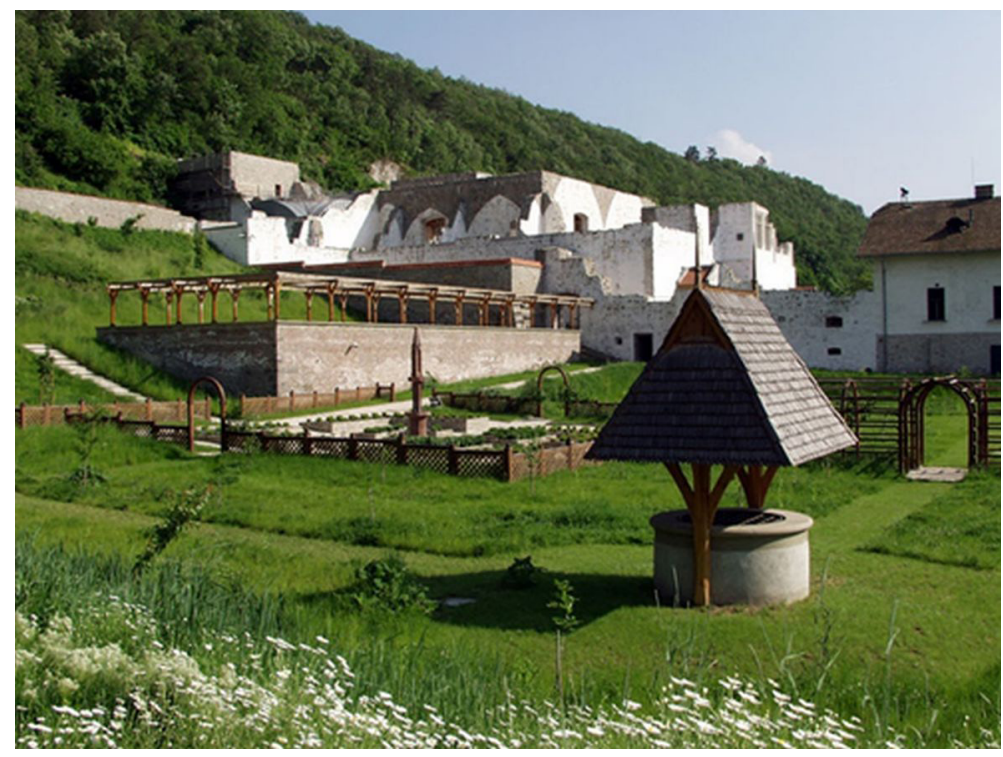

Fig. 8. Renovated Renaissance garden detail with a dwell, terrace, trellis and compartimented flower garden in the Royal Palace from Visegrád, Hungary. Source: Photo by the author, 2014

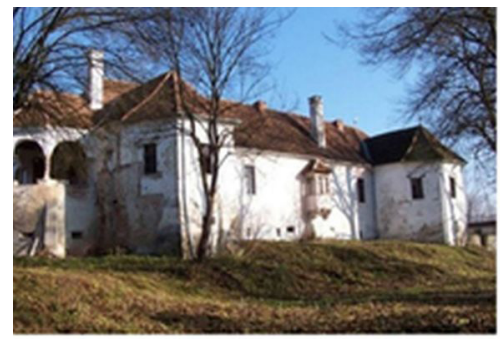

(a)

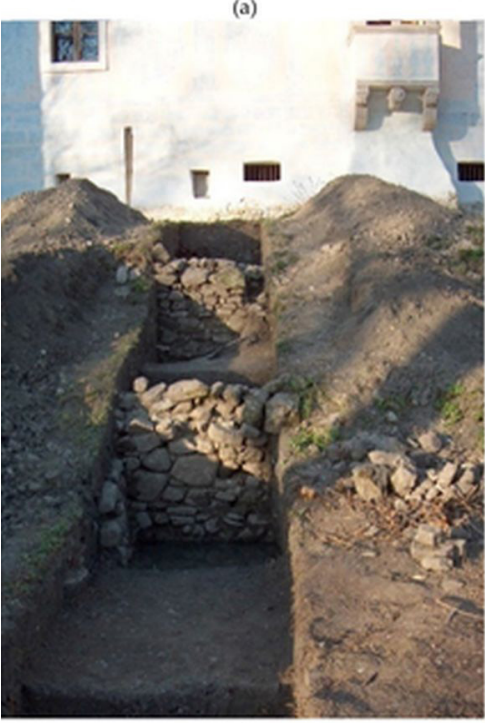

(c)

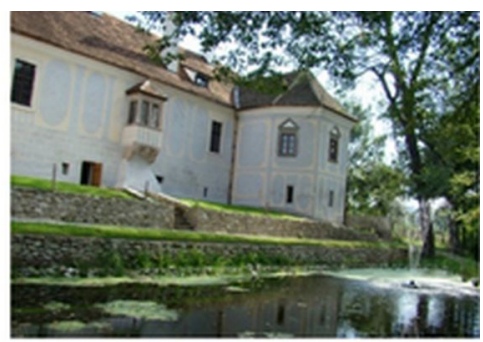

(b)

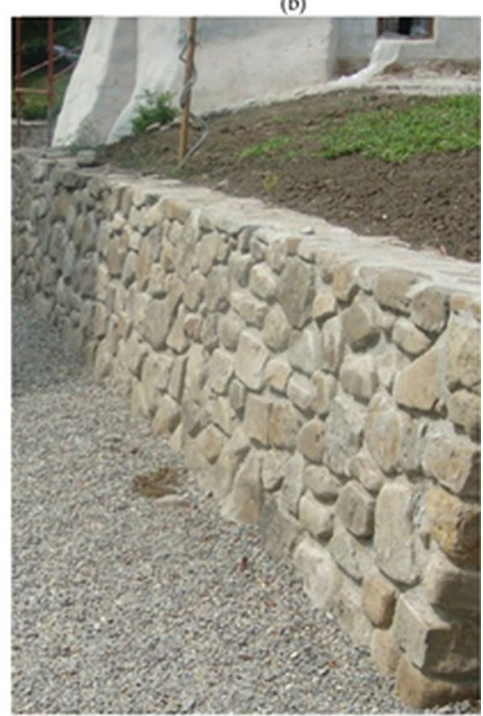

(d)

Fig. 9. The northern façade of the Kálnoky castle towards the pond with the retaining walls rooted in the Renaissance, in 2014 (a) and after the reconstruction in 2016 (b). The archaeological excavation of the retaining wall (c) and the renewed retaining wall (d). Source: photos by the author, 2017

(Fekete - Sárospataki - Rudd - Weiszer, 2014) 
sance castle/residential garden and the surrounding landscape, along with its importance from a landscape-aesthetic perspective.

- The past years have witnessed exemplary restorations of Renaissance gardens at the sites in the Carpathian Basin. Amongst others, the royal palace garden in Pozsony (Bratislava), Slovakia, the palace garden in Visegrád, Hungary (Figure 8), or the Kálnoky castle garden in Miklósvár (Miclosoara), Romania (Figure 9). Given that historical data and information about the actual site was lacking, the basis for the restorative work was oftentimes an overall and detailed case study of the historical period in question, the exploration and use of the possible garden historical analogies. It is to this process that the research provides fundamental help.

\section{References}

B. Nagy, M. (1970): Reneszánsz és barokk Erdélyben [Renaissance and Baroque in Transylvania] Bucharest, Kriterion

B. Nagy, M. (1973): Várak kastélyok udvarházak, ahogy a régiek látták [Fortresses, castles and manor houses in ancient times] Bukarest, Kriterion Könyvkiadó

Bicsok, Z. - Orbán, Zs. (2011): „Isten segedelmével udvaromat megépítettem..." Történelmi családok kastélyai Erdélyben. Gutenberg Kiadó, Csíkszereda

Bíró, J. (1943): Erdélyi kastélyok. [Transylvanian Castles] Singer és Wolfner, Budapest

Brink van den, A. - Bruns, D. - Tobi, H. - Bell, S. (2016): Research in Landscape Architecture. Methods and Methodology. London and New York, Routledge

Creighton, O. H. (2009): Designs upon the Land: Elite Landscapes of the Middle Ages. Woodbridge, Boydell Pres

Cselebi, E. (1985): Evlija Cselebi török világutazó magyarországi utazásai 1660-1664 [Evlija Cselebi's Journey in Hungary 1660-1664], Budapest

Csérer, L. (1929): Régi erdélyi kertek [Old Transylvanian Gardens], Kolozsvár, Pásztortűz, 1929/15 évf, 9. sz. 199-200.
Csoma, Zs. - Tüdős, S. K. (2010): Virág és virágkultúra a késő reneszánsz erdélyi kertekben (16-17. század) [Flower and Flower Culture in Late Renaissance Transylvanian Gardens (16th17th centuries)], Korunk, Kolozsvár, January 2010, pp. 24-32.

Csőre, P. (1997): Vadaskertek a régi Magyarországon, [Deer parks in Hungary] Budapest, Mezőgazdasági Kiadó

Dercsényi, D. (1951): Visegrád műemlékei [Monuments of Visegrád], Közoktatásügyi Kiadóvállalat, Budapest

Emich, G. (1886): A múkertészet múltja és jelene hazánkban [The past and the present of the Garden Art in Hungary] Kertészeti Lapok, Budapest

Encyclopedia Britannica, 1998. In: https://www. britannica.com/topic/history-of-Hungary, accessed on 12. February, 2020.

Fekete A. (2012): Az erdélyi kertművészet. Szamos menti kastélykertek. [Transylvanian Garden History. Castle gardens along the Szamos River] Kolozsvár, Művelődés Műhely

Fekete, A. (2004): Kolozsvári kertek, [Gardens of Kolozsvár] Kolozsvár, Művelődés Műhely

Fekete, A. (2006): Erdélyi nemesi rezidencia-kertek I. [Noble residencies in Transylvania I] In: 4D Tájépítészeti és Kertművészeti Folyóirat, $2006 / 3$

Fekete, A. (2007): Transylvanian Garden history. Castle gardens along the Maros River, Kolozsvár, Művelődés Műhely

Fekete, A. (2008): Lugaskert, filegória, halastó Erdélyi reneszánsz kertemlékeinkből, [Trellis, pavilion, fishpound - Renaissance garden heritage in Transylvania] Kolozsvár, Korunk, 2008. 3. folyam, 19. évf. 7. sz

Fekete, A. - Sárospataki, M. - Rudd, M. - Weiszer, Á. (2014): Reamenajarea peisagistica a parcului aferent castelului Kálnoky din Mislosoara [Miklósvár, RO - Restauratino plan of the Kálnoky castel garden], Engedélyezési és kiviteli tervdokumentáció, Megrendelő: Kálnoky Alapítvány, Miklósvár, Románia

Fényes, E. (1851): Magyarország Geographiai szótára [Geographical Dictionary of Hungary] I-IV. Pest

Gy. Dávid, Gy. (2001): A bonchidai Bánffy kastély, [The Bánffy castle of Bonchida] Kolozsvár, Polis

Herczeg, Á. (2000): A reneszánsz táj Magyarországon, [The Renaissance Landscape in Hungary] Budapest, Földgömb, XVIII. 3.

Herczeg, Á. (2006): Szép és kies kertek. A kora reneszánsz kertek Itáliában és Magyarországon [Early Renaissance gardens in Italy and 
Hungary] Pro-Print, Székelyudvarhely

Hobhouse, P. (1992): Plants in garden History. Chrysalis, London

Hunt, J. D. (1996): Garden and Grove. The Italian Renaissance Garden in the English Imagination, 1600-1750, University of Pennsylvania Press

Hyde, E. (2016): A Cultural History of Gardens in the Renaissance. Bloomsbury Academic. Reprint edition

Köpeczi, B. et al (1986): Erdély története I-III [History of Transylvania I-III], II. köt. Akadémiai Kiadó, Budapest

Kovács, A. (2003): Késő reneszánsz építészet Erdélyben 1541-1720, [Late Raenaissance architecture in Transylvania 1541-1720], Teleki László Alapítvány - Polis Könyvkiadó, Kolozsvár

Lazzaro, C. (1990): The Italian Renaissance Garden: From the Conventions of Planting, Design, and Ornament to the Grand Gardens of Sixteenthcentury Central Italy, Yale University Press

Marczali, H. - Áldássy, A. - Borovszky, S. - Csuday, J. - Fogarassy, A. - Geréb, J. - Goldzicher I. Gyomlay, Gy. - Mika, S. - Schönherr, Gy. (2001): Magyar- és Erdélyország Bethlen Gábor halála évében [Hungary and Transylvania in the last year of Gábor Bethlen] In: Marczali et al. (2001): Nagy képes világtörténet I-XII kötet, VIII. Szekszárd

Morgan, L. (2016): The monster in the garden: the grotesque, the gigantic, and the monstrous in Renaissance landscape design. Penn Studies in Landscape Architecture, University of Pennsylvania Press

Ormos, I. (1967): A kerttervezés története és gyakorlata [The history and practice of garden design] Mezőgazdasági Kiadó, Budapest

Rapaics, R. (1940): Magyar kertek [Hungarian Gardens] Királyi Magyar Egyetemi Nyomda, Budapest

Steenbergen, C. - Reh, W. (1996): Architecture and Landscape. The Design Experiment of the Great European gardens and Landscapes. Prestel Verlag, Munich, Germany.

Stirling, J (1996): Magyar reneszánsz kertművészet a XVI-XVII században [Hungarian Renaissance garden art in 16-17 centuries] Budapest, Enciklopédia Kiadó

Sárospataki, M. (2014): Dendrológiai kertek a 19. századi magyarországi kertépítészetben. [Dendrological gardens in 19th century garden architecture in Hungary.] Doktori disszertáció. Corvinus University of Budapest, Budapest.
Strong, R.C. (1984): The Renaissance Garden in England. Thames and Hudson Ltd

Szabó, T. A. (2000): Erdélyi történeti kertek egy biológus szemével [Historic Gardens in Transylvania described by a biologist]. In: Galavics, G. Történeti kertek, MTA Művészettörténeti Kutatóintézet-Mágus Kiadó, Budapest

Szafranska, M. (1989): The philosophy of nature and the grotto in the Renaissance garden. The Journal of Garden History, Volume 9. https:// doi.org/10.1080/01445170.1989.10408269

Szakái, E. (1959): Mátyás király oroszlános díszkútjának rekonstrukciója [The reconstruction of the lion's dwell of King Mathias Corvinus], Művészettörténeti Értesítő, VIII. évf. 232-250, Akadémiai Kiadó, Budapest

Szikra, É. (2003): Egy XV. századi palotakert újjászületése (Mátyás király visegrádi kertjei) [The renewal of a palace garden from the 15'th century (The gardens of King Matthias from Visegrád)] In: Műemlékvédelem, 2003/3. 186192.

Takács, S. (1915-1917): Rajzok a török világból. [Drawings from the Ottoman times] Budapest, Akadémiai Kiadó I-III

Thoroczkai, W. E. (1923): A kert [The garden] Budapest, Pátria Kiadó

Toman, R. (1995): Az itáliai reneszánsz: Építészet, Szobrászat, Festészet, Rajz [The Art of the Italian Renaissance: Architecture, Sculpture, Painting, Drawing], Kulturtrade Kiadó, Budapest

Tüdős, S. K. (1998): Székely főnemesi életmód a XVII. század alkonyán. [Szekler nobiliar lifestyle at the end of 17st century] Bukarest-Kolozsvár, Kriterion Könyvkiadó

Archival source: Magyar Tudományos Akadémia Levéltára Kemény család csekelaki levéltára, 1646, DD, Nr. 102 (AkadLt, Kemény) [The Archive of Hungarian Academy of Science, Kemény Family Archive]

Archival source: Magyar Tudományos Akadémia Levéltára Korda család levéltára, 1692, II.R. Fasc. 59, Nr.1 (AkadLt, Korda) [The Archive of Hungarian Academy of Science, Korda Family Archive]

Archival source: Magyar Tudományos Akadémia Levéltára Teleki család kendilónai levéltára limbus, 1679 (AkadLt, Teleki) [The Archive of Hungarian Academy of Science, Teleki Family Archive] 
Archival source: Magyar Tudományos Akadémia Levéltára. Jósika család hitbizományi levéltára limbus, 1756 (AkadLt, Jósika) [The Archive of Hungarian Academy of Science, Jósika Family Archive]

Archival source: Mappa della Transilvania e Provintie contique nella quales [B IX a 487/15], Hadtörténeti Intézet és Múzeum [Hungarian Museum and Institute of War Science], B IX a, B IX Ausztria-Magyarország, B I-XV. Európa

Archival source: MTA Könyvtár Kézirattár és Régi Könyvek Gyűjteménye [Library of Hungarian Academy of Science, Collection of Manuscripts and Old Books] 